\title{
Considerações históricas, jurídicas e ambientais brasileiras
}

\author{
Brazilian legal and environmental historical considerations
}

\author{
Krishna Schneider Treml ${ }^{1}$ \\ Jairo Marchesan ${ }^{2}$ \\ Sandro Luiz Bazzanella ${ }^{3}$
}

\section{Resumo}

Atualmente, a temática ambiental tem gerado discussões, divergências e aproximações entre países e regiões preocupadas com o bem-estar das atuais e futuras gerações. No Brasil, o Direito Ambiental é uma área jurídica relativamente nova, que tem seu marco histórico na Lei da Política Nacional do Meio Ambiente Lei ${ }^{\circ} 6938$, do ano de 1981. Sob tais perspectivas, constata-se que, especialmente ao longo dos últimos trinta anos, houve muita discussão científica e produção acadêmica e legislativa sobre o tema. Fundamentando-se na evolução histórica e jurídica, este artigo tem o propósito de analisar o progresso e a implementação das diretrizes legais socioambientais no Brasil, bem como as contradições e relações com o desenvolvimento local e nacional. Metodologicamente, é um artigo fundamentado na literatura, em estudos documentais, análises e interpretações de autores.

Palavras-chave: Meio Ambiente. Direitos Fundamentais. Desenvolvimento Regional.

\begin{abstract}
Currently, the environmental issue has generated discussions, divergences and approaches between countries and regions concerned with the well-being of current and future generations. In Brazil, Environmental Law is a relatively new legal area, which has its historic landmark in the National Environmental Policy Law - Law No.

\footnotetext{
${ }^{1}$ Doutoranda em Desenvolvimento Regional pela Universidade do Contestado (UnC). Mestre em Desenvolvimento Regional pela Universidade do Contestado (UnC) - Canoinhas (SC). Graduada em Direito pela Universidade do Vale do Itajaí (UNIVALI). E-mail: krishna_schneider@hotmail.com; ${ }^{2}$ Doutor em Geografia pela Universidade Federal de Santa Catarina (UFSC) e Professor do Programa de Mestrado em Desenvolvimento Regional Universidade do Contestado (UnC) - Canoinhas (SC). Orcid: https://orcid.org/o0oo-0001-9346-0185

E-mail: jairo@unc.br

3 Doutor em Ciências Humanas pela Universidade Federal de Santa Catarina (UFSC). Professor do Programa de Mestrado em Desenvolvimento Regional Universidade do Contestado (UnC) - Canoinhas (SC). Orcid: https://orcid.org/oooo-0002-9430-8684 E-mail: sandro@unc.br
} 
6938, of 1981. From such perspectives, it appears that, especially, throughout the In the last thirty years, there has been a lot of scientific discussion and academic and legislative production on the subject. Based on historical and legal evolution, this article aims to analyze the progress and implementation of social and environmental legal guidelines in Brazil, as well as the contradictions and relations with local and national development. Methodologically, it is an article based on the literature, on documentary studies, analyzes and authors' interpretations.

Keywords: Environment. Fundamental rights. Regional development.

\section{Introdução}

Sabe-se que as mudanças relacionadas ou advindas da sociedade humana com ou sobre os bens naturais vêm acontecendo de forma dinâmica, acelerada e intensa, especialmente após a modernidade, em razão das premissas inerentes ao pleno modo de produção e consumo.

Nesta perspectiva, a partir da era moderna, a natureza se tornou objeto de experiências e pesquisas científicas, que resultaram em avanços tecnológicos, porém, paradoxalmente ou com efeitos colaterais que se desdobraram em crescentes prejuízos ambientais. "O homem, ministro e intérprete da natureza, faz e entende tanto quanto constata, pela observação dos fatos ou pelo trabalho da mente, sobre a ordem da natureza" (BACON, 1973, p. 19). A partir desse contexto até a atualidade, a temática ambiental tem sido alvo de impasses, incompreensões e incongruências, mas, também, de aproximações entre povos e países, especialmente aqueles que almejam compatibilizar o uso dos ecossistemas e o bemestar humano e social à luz do desenvolvimento regional4.

Contrariando os preceitos inerentes ao Estado Democrático de Direito 5 , será possível verificar neste artigo que inexiste a almejada sincronia entre os preceitos sociais, econômicos e ambientais, bem como, que as vicissitudes suportadas pelo ambiente e pela sociedade brasileira estão intrinsecamente vinculadas ao contexto histórico colonial, constitutivo deste país.

Nestas perspectivas, o debate ambiental não se restringe às questões jurídicas inerentes ao meio ambiente, mas aborda aspectos históricos, políticos,

\footnotetext{
4 Concebe-se desenvolvimento regional como o bem-estar econômico, social, cultural da sociedade humana, bem como, o estabelecimento de relações harmoniosas, de respeito, cuidado e uso parcimonioso dos bens naturais.

5 Segundo o Art. $1^{\circ}$ da Constituição Federal de 1988: "A República Federativa do Brasil, formada pela união indissolúvel dos Estados e Municípios e do Distrito Federal, constitui-se em Estado Democrático e tem como fundamento: Parágrafo Único: Todo poder emana do povo, que o exerce por meio de representantes eleitos ou diretamente, nos termos desta Constituição".
} 
sociais, econômicos e culturais à luz de perspectivas interdisciplinares, que refletem as relações da sociedade humana entre si e desta com a natureza, conforme se analisará a seguir.

\section{Aspectos da trajetória da legislação ambiental brasileira}

\subsubsection{Período Colonial}

A constituição da sociedade brasileira e de suas instituições está indissociavelmente vinculada em suas origens relativas às prerrogativas civilizatórias europeias, especialmente a portuguesa. Neste contexto, no dia $1^{\mathrm{o}} \mathrm{de}$ maio de 1500, Pero Vaz de Caminha ${ }^{6}$ escreve a primeira carta ao Rei Manuel I7, Rei de Portugal à época, cuja narrativa permaneceu mais de três séculos nos arquivos portugueses, publicada no ano de 1817.

Referida carta relata fatos minuciosos do primeiro encontro entre os marujos portugueses e as comunidades indígenas, desde o comportamento, vestes, detalhes sobre os enfeites dos índios, até relatos pormenorizados sobre a sua inocência, os entendimentos entre eles por meio de gestos, tudo registrado em detalhes, caracterizando os esforços do escrivão de manter-se fidedigno aos fatos e acontecimentos que havia presenciado, permitindo ao leitor (o rei) uma compreensão pormenorizada do ocorrido (CASTRO, 2002).

Dentre os relatos da missiva, encontra-se um trecho revelador do que os portugueses subentenderam, diante da gesticulação dos índios:

O Capitão, quando eles [índios] vieram, estava sentado em uma cadeira, bem vestido, com um colar de ouro mui grande ao pescoço, aos pés, uma alcatifa por estrado. Sancho de Tovar, Simão de Miranda, Nicolau Coelho, Aires Correia, e nós outros que aqui na nau com ele vamos, sentados no chão, pela alcatifa. Acenderam-se tochas. Entraram. Mas não fizeram sinal de cortesia, nem de falar ao Capitão nem a ninguém. Porém, um deles pôs olho no colar do Capitão, e começou de acenar com a mão para a terra e depois para o colar, como que nos dizendo que ali havia ouro. Também olhou

\footnotetext{
6 "Pero Vaz de Caminha achava-se na esquadra de Pedro Álvares Cabral em viagem para a Índia, como escrivão nomeado para a feitoria de Calicute. Considerando-se amigo do rei, em virtude de serviços prestados à Coroa pelo pai e avós, valeu-se da oportunidade de comunicar a nova do descobrimento" (CASTRO, 2002, p.13).

7 D. Manuel I, Rei de Portugal, que faleceu em Lisboa, no Paço da Ribeira, em 13 de dezembro de 1521, com 52 anos.
} 
para um castiçal de prata, e assim mesmo acenava para a terra e novamente para o castiçal como se lá também houvesse prata (CASTRO, 2002, p. 96).

Baseando-se na narrativa acima exposta, verifica-se que, desde os primórdios da conquista das terras da colônia, esteve em curso um processo de intensa instigação à exploração política e socioambiental realizada pelos portugueses. Assim, Portugal, na condição de metrópole, impôs às suas colônias práticas econômicas extrativistas, calcadas na exploração dos bens naturais e assentadas no imperativo de rendas e lucros derivados da extração dos referidos bens, dentre eles pau-brasil, minérios, entre outros produtos e riquezas. Como bem explica Faoro: "Fundar uma vila ou povoação, ato de benemerência régia, era converter em moeda sonante o produto bruto da fazenda agrícola” (FAORO, 2001, p. 19).

Naquele cenário, os bens naturais, assim como os bens públicos e privados não se distinguiam. A conquista de novos territórios se incorporava ao patrimônio da realeza lusitana. Era medida indispensável para o sustento dos privilégios da realeza, das necessidades e manutenção das estruturas estamentais constitutivas do estado absolutista e patrimonial português.

A história daquele período se caracterizou pelo processo de colonização como uma atividade marítima e comercial, que culminou no povoamento da costa brasileira, com fins exclusivamente extrativistas e mercantis. A colônia se tornou objeto de exploração pelo Estado patrimonial português, em que as questões fiscais, marítimas, religiosas, jurídicas, entre outras, estavam todas vinculados ao Rei e ao estamento, como elucida Faoro:

As conquistas e colônias dão ênfase aos órgãos colegiados, preocupando os soberanos em coordenar e centralizar a administração e os negócios ultramarinos. Os Tribunais, conselhos e casas, subordinam-se, frouxa ou rigidamente, ao comando dos ministros régios. Os interesses comerciais e fiscais inspiram a organização dos estabelecimentos formados ao lado da atividade diretamente desenvolvida pelo Estado, sistema próximo das modernas autarquias (FAORO, 2002, p. 210).

O processo de colonização fundamentava-se no Direito Romano ${ }^{8}$ e no Direito

\footnotetext{
8 Os preceitos jurídicos oriundos de Roma constituem-se uma das mais importantes fontes do direito nos países ocidentais, cujos princípios e institutos fundamentam o Direito Civil brasileiro.
} 
Canônico9, que vigoravam em Portugal por meio das Ordenações Afonsinas de 1446, em homenagem ao Rei Dom Afonso ${ }^{10}$. Esta primeira compilação de leis esparsas, dividida em cinco livros, perdurou até a primeira publicação das Ordenações Manuelinas, em 1514. A referida lei, que substituía os forais e os costumes até então vigentes, tinha como uma das preocupações coibir o corte de árvores frutíferas, haja vista a escassez de alimentos, especialmente cereais, à época, na Europa. Por obviedade, o referido diploma legal foi incorporado e estendido à colônia, em razão da extensão do modelo lusitano aos colonizados.

Entre outras variáveis, e sobretudo a partir dessa preocupação alimentícia, foram criadas e implementadas as sesmarias ${ }^{11}$, com o objetivo de cultivar o solo e abastecer a população da metrópole com alimentos oriundos da colônia. Posteriormente, as sesmarias ganharam um segundo sentido - o de povoamento -, conforme disciplinado nas Ordenações Manuelinas e Filipinas ${ }^{12}$, consideradas atualizações legislativas.

Sob este enfoque, no que tange à vasta jurisdição, à época, as ordenações ofereciam a comprovação da intensa interferência da metrópole na vida da colônia, consolidando a gestão meticulosamente articulada, a qual se caracterizava por um conflito de atribuições públicas e privadas, como elucida Faoro:

As Ordenações Afonsinas, Manuelinas e as Filipinas regulam essa unidade de governo, nascida de preocupações fiscais do soberano, com o estímulo de motivos militares e de defesa, sempre alheias ao espírito automista do self-government anglo saxão (FAORO, 2001, p. 216).

A (in) gerência e a dominação política e econômica da metrópole sobre a colônia foi realizada por intermédio de uma hierarquia de atribuições e cargos, cujas

\footnotetext{
9 O Direito Canônico conceitua-se como o conjunto de normas jurídicas constituídas com o propósito de organizar e regular os assuntos que envolvem a igreja católica e seus fiéis, mediante princípios advindos das leis sacramentais da própria estrutura institucional da igreja.

${ }^{10}$ As Ordenações Afonsinas correspondem a uma coletânea de leis e de diversas fontes jurídicas promulgadas durante o reinado de D. Afonso V. São a primeira compilação oficial de Direito do reino e inserem-se num período de influência do Direito Comum, no qual o rei legisla para esclarecer, completar ou inovar (NUNO, 1981, p.17).

${ }^{11}$ Sistema de distribuição de terras pela Coroa Portuguesa, com o objetivo de cultivar e colonizar o novo território (FAORO, 2001). Legalmente, significava o título de posse de demarcada porção de terra ao donatário, com o objetivo de caracterizar a ocupação luso-brasileira na colônia, a qual estava condicionada ao cultivo e respectivo pagamento de foro e de dízimo sobre produção pelo sesmeiro à Coroa Portuguesa.

${ }_{12}$ As Ordenações Manuelinas do Senhor Rey Dom Manuel foram incorporadas, na sua grande maioria às Ordenações Afonsinas, em 1521. Já as Ordenações Filipinas, de 1595, é uma compilação de todas as leis de Portugal à época (WAINER, 1993).
} 
atividades eram regulamentadas por uma gama de documentos, decretos, editais, normas e leis, segundo corrobora Wainer:

Por outro lado, para proteger a exploração e regulamentar o comércio das riquezas naturais e o trabalho da mão de obra escrava de índios e negros no Brasil-Colônia, foram sendo editadas leis suplementares, conhecidas por legislação extravagante às Ordenações Filipinas e aos forais. Nela destacavam-se, além dos regimentos, as cartas de leis, alvarás, cartas régias, provisões e avisos Reais (WAINER, 1993, p. 199).

No que concerne à exploração do pau-brasil, a monarquia portuguesa compreendia que as referidas árvores eram uma riqueza permutável, e, por isso, arrendava as terras da colônia aos cristãos novos, para que eles explorassem a madeira existente, especialmente na costa brasileira. O referido acordo se tornou um modelo padronizado realizado na época, uma vez que trazia, subentendido, o encargo de descobrir e defender a terra (FAORO, 2001). No que tange aos procedimentos, Faoro explica: "os soldados, oficiais e companhias de ordenança escolhidos pela Coroa Real, vigiavam a costa brasileira com o objetivo de guardar o Pau-brasil, sob os interesses lusos, em especial do Conselho Ultramarino” (FAORO, 2001, p. 221).

Foi nesse período que se constituíram as primeiras legislações voltadas à preservação de certas espécies presentes nas florestas brasileiras, tal como ressalta Antunes: "No século XVII foi elaborado o Regimento do Pau-brasil, pelo qual ficava proibido o corte de Pau-brasil sem expressa autorização das autoridades públicas” (ANTUNES, 2017, p. 891), leia-se a Corte Portuguesa. O corte e a exploração da preciosa madeira somente poderiam ser realizados mediante a licença ou autorização Real, assim como todas as demais atividades relacionadas aos recursos naturais da colônia. A Coroa portuguesa vigiava, interferia e limitava todas as atividades realizadas, burocratizando e lucrando em todos os níveis. E assim o ordenamento jurídico daquela época cumpria seu escopo político e econômico, contribuindo com as demandas econômicas da metrópole, uma vez que nutria como objetivo povoar e explorar o território brasileiro. Faoro contextualiza:

O poder público responsável e atendo à povoação do litoral esteve presente nessa jornada de três séculos não apenas para legalizar a situação que se criava com o alargamento da base física. Fez-se sentir, igualmente, para incentivar o movimento que levou ao extremo norte, ao extremo sul e ao oeste e assegurar ao Brasil as 
áreas amazônicas, gaúchas e mato-grossenses (FAORO, 2001, p. 181).

Neste contexto, os atos praticados pelos conquistadores tinham um fim em si mesmo, qual seja, expandir e manter todos os recursos vistos no horizonte, bem como realizar obras com o fim de possibilitar a monopolização e o privilégio exclusivo na extração de tais recursos, como prossegue Faoro:

\begin{abstract}
Os conquistadores podiam cativar legalmente a indiada, recebiam vastas concessões territoriais, iam autorizados a distribuir hábitos e patentes aos companheiros mais esforçados. Estevão Ribeiro Bayão Parente, Matias Cardoso, Domingos Jorge Velho e outros fixam este curioso tipo; geralmente, não tornavam à pátria e deixavam sinais de suas passagens e herdeiros de seu sangue em Minas Gerais, na Bahia, em Alagoas e alhures: mas o maior serviço que prestaram constituiu em ligar o Tietê e o Paraíba do Sul ao São Francisco, através da Mantiqueira, construindo e levando rio abaixo canoas para as quais não havia aqui madeira própria, e auxiliarem os curraleiros a se estenderem até o Parnaíba (FAORO, 2001, p. 180/181).
\end{abstract}

E, assim, o estamento português torna-se responsável pelas vicissitudes jurídicas, políticas, sociais e econômicas originadas na colônia. Segundo Faoro, "tudo parte das origens. O rei é o senhor das terras, das minas, do comércio e do círculo patrimonialista em que se consolidou e se expandiu o reino" (FAORO, 2001, p. 259). Neste contexto, evidencia-se que a perspectiva colonialista portuguesa conseguiu, desde os primórdios, controlar a economia colonial e implantar um modelo produtivo pautado no ramo primário e extrativista da economia, incidindo na dinâmica social, política, econômica jurídica e ambiental, sem aferir se o mesmo era compatível e se adequava-se à realidade da sociedade brasileira.

Estas e outras análises da colônia em solo brasileiro esclarecem aspectos originários relativos a estrutura política, da concentração fundiária, da exploração intensa dos bens naturais e das pessoas, por intermédio do extrativismo escravagista, conferindo operacionalidade ao processo de colonização. Isto, evidentemente, sob a capa do Estado Português.

Nesta breve exposição do período colonial é possível constatar que as medidas jurídicas, políticas, sociais e econômicas, bem como a edificação de infraestrutura na terra colonizada tinham como objetivo viabilizar as condições de 
mercantilização da matéria-prima da colônia, potencializando a acumulação e a reprodução dos interesses dos colonizadores.

Com fundamento nessas premissas, constata-se que o período colonial foi caracterizado por relações político-econômicas, as quais eram articuladas pela coroa portuguesa em face à colônia, e se traduziam pela obtenção de matéria-prima escassa (bens naturais e alimentícios), que resultaram na evidente exploração dos bens naturais que aqui haviam e da opressão dos povos nativos que neste território residiam.

Num cenário contemporâneo, constata-se que esta condição exploratória se perpetua no Brasil e nos demais países marginalizados, desde os primórdios. Um exemplo desta interferência extrativista exercida pelos oligopólios em face aos países ditos em desenvolvimento é a implementação das monoculturas em tais países, os quais são detentores de condições naturais favoráveis ao desenvolvimento e cultivo de determinados produtos, como esclarece Porto-Gonçalves:

De início, a generalização das monoculturas esteve limitada pela
questão da matéria, na sua relação espaço-tempo, isto é, pela
questão energética. A primeira fase da constituição do sistema-
mundo moderno-colonial esteve associada à exploração de
produtos de alto valor por unidade de peso, por meio da energia
humana submetida a regimes de exploração brutais. A presença
física do dominador e o sistema colônia, com toda a sua brutalidade,
compunham o sistema na sua materialidade energética ao garantir
por esses meios a separação entre o lugar de produção e os lugares
de comercialização, distribuição e consumo (PORTO-
GONÇALVEZ, 2006, p. 29).
(PORO

Sob tais condições, tem-se que, desde o Brasil colonial até os dias atuais significativa concentração de terras produtivas brasileiras sob o domínio de grandes potências mundiais, causando o intenso e contínuo desaparecimento de pequenos produtores e dos agricultores de subsistência que, em razão da perda, venda ou desapropriação das terras cultivadas, se veem forçados a abandonar a produção agrícola e muitas vezes migrarem para trabalhar como operários assalariados nos centros urbanos mais próximos.

Além disso, a expansão das monoculturas pelos grandes polos hegemônicos em determinados territórios destrói a fauna e a flora dos ecossistemas, bem como proporciona a lucratividade dos oligopólios na produção de sementes e demais insumos necessários ao cultivo. Nestas condições, verifica-se que, em nome da 
manutenção do progresso dos polos mundiais não são pesados ou compensados os impactos e desequilíbrios decorrentes da atividade econômica no território nacional, tais como a (re) distribuição da população rural e a degradação ambiental, especialmente o desaparecimento das zonas úmidas, as quais, transformadas em terrenos com silviculturas ou agriculturáveis, perdem a enorme biodiversidade local que abrigavam. Ou seja, um equivocado desenvolvimento econômico, elitista, que traz implícito, na significativa maioria das vezes perda da qualidade de vida e dos ecossistemas dos países marginalizados.

Ademais, "neste período de globalização neoliberal, generaliza-se a financeirização das empresas, já que as inversões produtivas decrescem continuamente a favor das financeiras, e por outro lado, há a hipertrofia dos ganhos financeiros nos países da periferia" (PORTO-GONÇALVES, 2006, p. 38), gerando um balanço negativo nas contas públicas e representando significativas reduções de investimentos nas áreas sociais e ambientais.

Neste contexto de concentração de rendas, bens e recursos por minorias, constata-se severas concorrências, como as disputas desleais, concentração de renda, promoção de guerras entre países pelas conquistas de mercado e obtenção de matéria-prima, bem como a instituição e manutenção da dívida externa, submetendo os países periféricos à condição de reféns dos países desenvolvidos, como assinala Porto-Gonçalves:

De fato, a fantástica dívida externa da maior parte dos países do mundo reduzidos a condições de semicoloniais, conforme assinalamos, tem sido objeto de uma verdadeira chantagem política onde organismos financeiros internacionais impõem políticas de ajuste estrutural que, no fundo, agravam a pilhagem ambiental e os problemas naturais (PORTOGONÇALVES, 2006, p. 38).

Neste contexto, o fluxo mercantilista decorrente da busca de energia e da matéria-prima continua a manter o ciclo do modelo decorrente do período colonial tradicional, no qual "não só se disputam mercados para a venda dos produtos, mas, sobretudo, para se obter as fontes de matéria-prima ou controlar os lugares e regiões estratégicas" (PORTO GONÇALVES, 2006, p.32), quando os espaços e as questões inerentes à geopolítica se tornam fundamentais e decisivos nesse processo. 


\subsubsection{Período Imperial}

O período imperial brasileiro (1822 - 1889) se deu logo após o início da Revolução Francesa, a partir de 1789, na qual estavam presentes os pressupostos de liberdade, igualdade e fraternidade - que ressoaram pelo mundo - e ocasionaram, no Brasil, a proliferação de ideais liberais, especialmente pelos jovens pertencentes às famílias brasileiras mais abastadas, que, na época, estudavam na Europa. Do continente europeu os estudantes traziam ideias liberais que influenciariam decisivamente nas futuras diretrizes do país, os quais, somados a experiência da independência norte-americana repercutiram e contribuíram para a transição do Estado absolutista para o Estado liberal no Brasil.

Neste contexto histórico, em atenção à concretização formal e material da estrutura de poder e de direitos preeminentes, foi outorgada, no ano de 1824, por D. Pedro I, a primeira Constituição brasileira, denominada Constituição Política do Império do Brasil, após a independência do Brasil do reino de Portugal, a qual permaneceu vigente até 1889 , ano da deposição da Monarquia e instauração da República pelos militares.

Naquele período histórico, em que pese o texto constitucional tenha obtido certa parcela de êxito no que concerne especialmente à limitação de poderes (referida Carta proclamou os direitos do homem e consagrou a separação de poderes), é importante ressaltar que os primeiros artigos da carta política brasileira foram formalizados sob as premissas das raízes do colonialismo e dos estreitos vínculos remanescentes e ainda mantidos com Portugal.

Nestas condições, sob inúmeras circunstâncias conflituosas inerentes às revoltas e insurreições vivenciadas em razão da dissolução da Assembleia Constituinte de 1823, por D. Pedro I, a Constituição Política do Império do Brasil de 1824 recebeu incontestável relevância na história constitucional brasileira, pois se adaptou às condições econômicas e sociais da época.

Sob as perspectivas da independência da colônia, ainda mantendo a estrutura de Estado Imperial centralizado e herdado de Portugal, a Constituição Imperial de 1824 não fez qualquer referência ao meio ambiente e à proteção dos bens naturais. Dito diploma legal determinou a elaboração do Código Civil e Criminal em substituições às centenárias Ordenações Filipinas que ainda vigoravam na colônia, ante a falta de legislação subsequente. 
Em cumprimento ao disposto na Carta, em 1830 foi publicado o Código Criminal ${ }^{13}$. Já em 1850 foi promulgada a Lei $\mathrm{n}^{\circ}$ 601, conhecida como Lei das Terras, que estabeleceu que: (i) a aquisição de terras somente poderia se dar mediante compra; (ii) a proibição da ação de usucapião sobre terras públicas; e (iii) disciplinou diretrizes sobre a ocupação do solo, dentre outros.

A ausência de comprometimento constitucional com as questões ambientais fica evidenciada na promulgação da Constituição Federal de 1824 e nos textos constitucionais subsequentes, a seguir analisados, ainda que, nesse período tenha sido constatado significativo avanço nas fronteiras agrícolas, o que, consequentemente continuou o processo de devastação de matas e florestas brasileiras.

Ainda sob a questão ambiental no período imperial brasileiro de 1822 a 1899, expõe Wainer:

Mesmo após a independência do Brasil, as leis que visavam a conservação das florestas de nada valiam. Não existia uma conscientização coletiva, no sentido de respeitá-las, fazendo com que fossem cumpridas. O problema era bilateral, pois estava tanto na falta de civismo do corpo administrativo, como na falta de civilidade por parte da população (WAINER, 1993, p. 203).

Cabe ressaltar ainda, que no contexto do Brasil Império foram edificadas obras estruturais importantes com o objetivo de promover o desenvolvimento interno, como os transportes. Nesse período foram sancionadas a Lei de 29 de agosto de 1828, estabelecendo as regras para a execução de obras públicas, como a navegação fluvial; a abertura de canais e de estradas; e o Decreto de 23 de outubro de 1832, objetivando ligar a capital às províncias da Bahia, do Espírito Santo e de Minas Gerais, para fomentar o progresso econômico nacional.

No entanto, há de se destacar que Don Pedro II pode ser considerado o Imperador ambientalista. "O Imperador tinha sensibilidade e profundo interesse pelas questões ambientais, tais como, clima, chuvas, enchentes, estiagem, saneamento básico, inclusive com a implementação de políticas públicas ambientais" (VIPIEVSKI JÚNIOR e MARCHESAN, 2021).

\footnotetext{
${ }^{13}$ Reconhecendo a inaplicabilidade das Ordenações Filipinas, a legislatura do Código Criminal de 1830 foi resultado da conjuntura política vivenciada na nova unidade política que se formava à época. Seguindo o padrão previamente positivado no Ocidente, materializou em seu texto a recusa dos parlamentares ao modelo de soberania concentrado na figura do monarca, quando, por exemplo, abdicou da regulamentação dos delitos conhecidos como "lesa-majestade" a "atentado à vida do imperador". Naquele momento, houve consentimento entre os parlamentares sob a premissa de se legislar exclusivamente sobre matérias criminais.
} 
Mediante essa dinâmica imperial, é possível considerar que o ordenamento jurídico se constituiu na materialização do poder de disciplinar e ordenar as relações sociais, políticas e econômicas na colônia. Ou seja, preservava interesses de determinados grupos, cuja ação econômica insidia diretamente sobre as questões ambientais de outros grupos. Neste sentido é possível questionar: qual legado nos foi deixado e possivelmente preservado até os dias atuais, no que concerne ao ordenamento jurídico e às questões ambientais advindas do período imperial?

Desde aquele período histórico até os dias atuais constata-se que, o fomento à industrialização e ao progresso estão pautados em discursos e em insipientes medidas que não atingem as premissas socioambientais regionais ou nacionais.

Os bens naturais mais preciosos do território brasileiro estão sendo depredados em nome de um equivocado desenvolvimento econômico e/ou regional que apenas contabiliza o fluxo de produtos, mercadorias e o progresso das empresas, sejam nacionais ou transnacionais. Nos parece lógico que, de algum modo o desenvolvimento deveria ser integral e compreender as condições naturais, tais como considerar o tempo e os limites da natureza, os benefícios ou serviços oferecidos pelos bens naturais, dentre outros, bem como, respeitar os aspectos sociais, tais quais o modo de vida das pessoas, seus costumes, práticas, hábitos e outros.

\subsubsection{Período Republicano}

A mudança do regime político, ocasionado pela Proclamação da República, em 15 de novembro de 1889 , concedeu tratamento tangencial à matéria ambiental, retirando o foco principal da infraestrutura e da atividade produtiva, que caracterizaram sobremaneira o período imperial.

Neste cenário, a primeira Constituição do período republicano e a segunda Constituição do Brasil independente foi promulgada em 1891 e denominada Constituição da República dos Estados Unidos do Brasil14, uma vez que foi inspirada no modelo estadunidense, que, em suma, permitia uma organização em consonância aos preceitos constitucionais, ao proclamar a união indissolúvel das

\footnotetext{
${ }^{14}$ A nomenclatura "Constituição da República dos Estados Unidos do Brasil” foi adotada, haja vista que os preceitos do diploma legal em referência seguiam o modelo prévio estabelecido na Constituição dos Estados Unidos da América, especialmente do sistema liberal norte-americano de organização federativa.
} 
Unidades Federativas.

No interior desse sistema político e econômico decorrem transformações profundas na estrutura de classes da sociedade brasileira, na configuração de uma nova estrutura ou configuração do Estado, bem como, inicia-se tardiamente pensar no desenvolvimento do modelo de crescimento econômico centrado no setor industrial.

No cenário político consolidou-se a formação de personalidades a quem eram conferidos poderes regionais dotados um misto de poder político e militar. A figura protecionista repleta de poderio - intitulada "coronel" - protegia, socorria e sustentava seus aliados, exigindo como contraprestação aos préstimos realizados, a obediência e fidelidade da população local. A esta relação política de subordinação, que acometeu o cenário político brasileiro durante décadas, deu-se o nome de coronelismo.

Por seu turno, naquele momento histórico, em que o voto era aberto e público, ou seja, diante da inexistência do sigilo, os coronéis exerciam poderes para que as pessoas fossem fiéis a eles ou ao seu candidato. Era o chamado "voto de cabresto", dando origem ao fenômeno denominado de "política dos governadores", que predominou no período da Primeira República do Brasil, compreendido entre os anos de 1891 e 1930.

Assim, a democracia implantada na Constituição de 1891 tinha caráter meramente decorativo, haja vista que, através do voto de cabresto, o que se instituiu no país foi uma oligarquia, dominada pelos Estados de Minas Gerais e São Paulo. E sob as perspectivas em que os coronéis elegiam os Governadores, os Deputados e os Senadores, inúmeras insatisfações surgiriam de uma população que almejava maior participação política e transparência no processo eletivo, estendendo inclusive o voto secreto às mulheres, que até aquele período não participavam do processo eleitoral brasileiro.

Sob estas circunstâncias, desenvolveram-se as propícias condições para a Revolução de $1930^{15}$ e o aparecimento de um líder carismático, que, inclinado para as questões sociais, tomaria o poder e acabaria com o coronelismo, e, consequentemente, com a política dos governadores. De fato, Getúlio Vargas

\footnotetext{
15 A Revolução de 1930 foi o produto de um movimento com o objetivo imediato de depor o governo de Washington Luís e impedir a posse de Júlio Prestes, eleito presidente da República. Esse movimento revolucionário foi considerado o marco inicial da Segunda República no Brasil.
} 
assumiu e logo promoveu o desarmamento dos coronéis, alargando as competências da União e intervindo nos Estados com o intuito certo de desconstituir a política dos governadores.

Referido período foi de suma importância histórica para o Brasil, pois, no entorno de 1930 dá-se início ao processo de modernização das relações produtivas, econômicas, sociais e políticas na sociedade brasileira. $\mathrm{O}$ advento do novo governo, sob a presidência de Getúlio Vargas, no período de 1930 a 1945, suscitou uma reorganização do poder, com a substituição das elites oligárquicas nacionais nas funções públicas, quando impulsionaram a ruptura com a Primeira República, num cenário em que Vargas sustentou o controle do processo de constitucionalização no país. Naquele período, Vargas assumiu a presidência do Brasil, provisoriamente, em nome do exército e da marinha, sem qualquer consulta oficial ao povo brasileiro.

Assim, a Primeira República representava uma determinada ordem social, política e econômica, substituída por outra, mediante as medidas adotadas pelo governo Vargas, as quais contemplaram a dissolução do Congresso Nacional, das Assembleias Estaduais, Câmaras Municipais e a destituição dos governadores de Estados.

Nesse contexto, Getúlio marca para o dia 03 de maio de 1932 eleições que elegeriam a Assembleia Constituinte - eleições que, mesmo com a eclosão da Revolução Constitucionalista de 1932, em São Paulo (vencida pelo governo), ocorreram e deram início à elaboração da Constituição de 1934. Sob tais condições, surgiu a primeira Constituição verdadeiramente social do Brasil, de caráter democrático e interventiva - o texto da Carta Política de 1934.

Entretanto, com base numa análise da constelação que apoiava o governo Vargas, à época, faz-se permissível constatar que foi mantido o predomínio oligárquico das elites dominantes, bem como não era possível identificar um setor econômico que pudesse, por si só, exercer suas atividades de forma voluntária e autônoma. Era a continuidade da mesma ordem econômica, social e política disfarçada de ruptura, com o intuito de acumular prestígio numa eventual posição política mais sólida, sem caracterizar uma oposição a nenhum dos lados.

Como as constituições refletem em nitidez o momento histórico precedido, sob um contexto de excepcionalidade, a Constituição da República dos Estados Unidos do Brasil, de 1934, regulava demandas sociais emergentes, como explica Cunha: "Deixava patente a disposição de organizar um regime democrático que 
assegure à Nação a unidade, a liberdade, a justiça e o bem social e econômico" (CUNHA, 1990, p. 60). Neste texto, originalmente constou a pioneira previsão do controle de constitucionalidade das leis brasileiras.

Ainda nesse contexto político, social, econômico e cultural, mais especificamente em 1934 foram publicados o Código de Mineração ${ }^{16}$; o Código Florestal ${ }^{17}$; Código de Caça e Pesca ${ }^{18}$; o Código de Águas ${ }^{19}$; diplomas legais que objetivavam o progresso e o fomento econômico nacional.

Sobre o Código de Águas e a produção de energia elétrica no país, elucida Antunes:

A água, portanto, foi enfocada sob o ponto de vista de que se constituía um elemento essencial para a produção de riquezas econômicas e desenvolvimento, especialmente como fonte geradora de energia elétrica (ANTUNES, 2017, p.1137).

Posteriormente, como consequência da crise provocada pela campanha presidencial, bem como estimulada pela situação internacional, em 10 de novembro de 1937 foi proclamado o Estado Novo, com a instituição da Constituição de 1937. Naquele período o país se encontrava num impasse econômico, político e social que eclodiu num movimento que deu origem à Carta de 1937.

Paralelamente, no cenário internacional, assistia-se à militarização da Alemanha durante o período após a Primeira Guerra Mundial, associado ao regime fascista dominante na Itália e ao regime comunista da então União Soviética. Nesta dualidade de ideias, o mundo dividia-se entre direita radical, representada pelo nazismo e fascismo, e um regime comunista, representado pela então União Soviética.

Para Vainer, "tal dicotomia ideológica se refletiu no Brasil com a fundação do Partido da Ação Integralista Brasileiro, de cunho fascista, encabeçada por Plínio Salgado e a fundação do Partido Comunista do Brasil, sob a chefia de Luis Carlos

\footnotetext{
${ }^{16}$ Instituído pelo Decreto ${ }^{0}$ 24.642, de 10 de julho de 1934 , sob a premissa de que o desenvolvimento da indústria mineira estava na dependência de medidas que facilitassem, incentivassem e garantissem as iniciativas privadas nos trabalhos de pesquisa e lavras dessas riquezas.

${ }_{17}$ Instituído pelo Decreto $\mathrm{n}^{0}$ 23.793, de 23 de janeiro de 1934, que disciplinou sobre as florestas existentes no território nacional, uma vez que constituíam bens de interesse comum a todos os habitantes do país.

${ }^{18}$ Instituído pelo Decreto $\mathrm{n}^{0}$ 24.672, de 02 de janeiro de 1934, regulou sobre a caça e a pesca no país. ${ }^{19}$ Instituído pelo Decreto ${ }^{0}$ 24.643, de 10 de julho de 1934, tendo como uma de suas premissas: permitir ao poder público controlar e incentivar o aproveitamento industrial das águas, de acordo com as necessidades e interesses da coletividade nacional.
} 
Prestes” (VAINER, 2010, p.176). Formava-se, então, sob as duas diretrizes, um país com premissas político-ideológicas paradoxais e contraditórias.

Sob a influência dos fundadores do Estado Novo, num conturbado cenário político, ainda sob um regime ditatorial, foi outorgada a Constituição dos Estados Unidos do Brasil, de 1937, conhecida no senso comum como "polaca", por suas semelhanças com a Constituição polonesa, de 1935. A Carta brasileira propunha a desagregação da "República Velha” ante seu caráter nacionalista, patriótica e intervencionista, cujos preceitos foram violados diversas vezes, em razão da falta de representatividade do Poder Legislativo.

Em matéria ambiental, a Constituição de 1937 atribuiu à União competência para legislar sobre minas, águas, florestas, caça e pesca, o que foi considerado um significativo avanço das premissas ambientais da época, se comparadas com a trajetória do Brasil Colônia, Império e República Velha.

Com o fim da Segunda Guerra Mundial, a conjuntura política da população brasileira à época, deflagrou significativas alterações, uma vez que o ambiente político se demonstrou propício à redemocratização - em decorrência da derrota dos regimes totalitários - na Europa.

No centro desta ruptura ideológica, Getúlio Vargas convocou eleições para dezembro de 1945, reafirmando sua pretensão de permanecer no poder, contudo, teve suas intenções obstadas, uma vez que foi deposto em 29 de outubro de 1945. Em contrapartida, Eurico Gaspar Dutra vence as eleições e convoca a Constituinte, que promulga a Constituição de 1946.

Por seu turno, a Constituição dos Estados Unidos do Brasil, de 1946, trouxe inovações no que tange à defesa ambiental do patrimônio paisagístico, histórico e cultural. Senão, vejamos: “Art. 175: as obras, monumentos e documentos de valor histórico e artístico, bem como os monumentos naturais, as paisagens e os locais dotados de particular beleza, ficam sob a proteção do Poder Público" (Constituição dos Estados Unidos do Brasil, 1946).

Decorridos alguns anos, mais especificamente em 1964, por meio de um golpe de Estado, as Forças Armadas assumiram o poder, apoiadas por movimentos políticos heterogêneos ${ }^{20}$ e por grupos mais conservadores da sociedade, quando

\footnotetext{
${ }^{20}$ Movimentos oriundos da sociedade civil, desencadeados em diversas regiões brasileiras, cujas reivindicações estavam diretamente relacionadas às reformas que possibilitassem melhores condições de vida à população. Um exemplo foi o movimento estudantil, que realizou intensas mobilizações nacionalistas, contraditando o controle social e político imposto pelo regime militar.
} 
depuseram o Presidente da República João Goulart. Na ocasião, sob as premissas da segurança e do desenvolvimento nacional, constituiu-se um governo que manteve a constituição de 1946 com algumas modificações, tais como: eleição indireta do Presidente, celeridade da discussão dos projetos de lei, sansões aos corruptos e subversivos, cassação de direitos políticos e mandatos legislativos (CUNHA, 1990).

Consequentemente, a Constituição do Brasil de 1967 foi imposta com o objetivo de instituir e legalizar o regime de ditadura no Brasil, quando os militares não invocaram o poder constituinte, mas utilizaram o Congresso Nacional. A Carta Política de 1967 tratou das questões ambientais nos moldes dos diplomas anteriores, ou seja, apenas disciplinou sobre as competências para as matérias ecológicas.

Mediante tensões internas causadas pela ausência de condições técnicas de manutenção da constituição vigente e com o intuito de alterar a Carta de 24 de janeiro de 1967 e promover uma reforma constitucional, foi promulgada pelos ministros militares, a Emenda Constitucional no 1, de 1969. Para Cunha, "essa Emenda é, materialmente, outra constituição, mas formalmente é uma alteração da Carta anterior" (CUNHA, 1990, p. 98).

O primeiro Ato Institucional ${ }^{21}$, em face do qual sobrevieram (AI-2, AI-3, AI4 e AI-5), substituía o texto constitucional anterior. Dava aos militares, por exemplo, o poder de suspender mandados legislativos, cargos de juízes e demais funcionários públicos, bem como possibilitava a intervenção em sindicatos de trabalhadores.

Entre fins dos anos 60 e primeiros anos da década de 70 do século XX se constituíram em países da América do Sul ditaduras militares, entre eles países como Chile, Argentina, dentre outros. Em suas especificidades, a ditadura no Brasil foi menos intensa em alguns momentos, mais violenta e repressiva em outros, ao longo do período de 1964 a 1985. Esse período pautou-se pela supressão dos direitos fundamentais do cidadão, pelo cerceamento da liberdade, pela perseguição aos opositores, pela repressão, exílio, tortura e assassinato de dissidentes do regime ditatorial, bem como pelo desenvolvimento e manutenção de uma economia alinhada aos interesses das elites brasileiras subserviente a interesses estratégicos e

\footnotetext{
${ }^{21}$ Instrumento jurídico utilizado pelo poder executivo para emendar arbitrariamente à Constituição Federal, ou seja, proceder alterações substanciais ao texto constitucional e revestir o ato de legitimidade.
} 
geopolíticos internacionais.

Paralelamente, naquele período de transição democrática, provocada pela inépcia do sistema implantado pelos militares desde 1964, foi promulgada a Lei ${ }^{\circ}$ 6931 \81, no Art. $3^{\circ}$, inciso I, intitulada Política Nacional do Meio Ambiente (PNMA), cujo diploma legal conceituou o meio ambiente como sendo: "o conjunto de condições, leis, influências e interações de ordem física, química e biológica, que permite, abriga e rege a vida em todas as suas formas".

Em consonância com o art. $2^{\circ}$, foram instituídos os princípios da PNMA, quais sejam: a) equilíbrio ecológico, considerando o meio ambiente como patrimônio público; b) racionalização do uso do solo, do subsolo, da água e do ar; c) planejamento e fiscalização do uso dos recursos ambientais; d) proteção dos ecossistemas; e) controle e zoneamento das atividades potencial ou efetivamente poluidoras; f) incentivo ao estudo e à pesquisa de tecnologia orientada ao uso racional dos recursos ambientais; g) acompanhamento do estado da qualidade ambiental; h) recuperação de áreas degradadas; i) proteção de áreas ameaçadas de degradação; e j) educação ambiental em todos os níveis de ensino.

No cenário político, mais especificamente no período que compreendeu os anos de 1974 a 1979, o Governo do General Ernesto Geisel promoveu uma pequena abertura política, a qual se tornava o primeiro passo rumo à redemocratização esperada e almejada pela população brasileira na época.

Já em 1979, o General João Baptista Figueiredo, Presidente do Brasil, concede anistia aos condenados por crimes políticos, momento em que retornaram ao país muitos artistas e intelectuais exilados. Por sua vez, as eleições diretas para Governador da República, que aconteceram no ano de 1982 mostraram quão impopular era o governo, a partir da vitória expressiva do PMDB (Partido da Mobilização Democrática do Brasil), principal oposição ao governo ditatorial. Tal vitória criou condições para que o povo pedisse eleições diretas também para Presidente da República, as quais ocorreram dois anos mais tarde.

Nos anos 80, mais especificamente em 1984, após inúmeros confrontos e movimentos que fomentavam a resistência à repressão e ao regime militar no país que foi palco de públicas e inquestionáveis tragédias, como prisões, torturas e crimes políticos - iniciou-se um movimento intitulado "Diretas, já", o qual objetivava restabelecer a democracia no Brasil por intermédio da eleição direta para presidente da república. 
Associadas às "Diretas, já", decorreu a expansão das periferias urbanas ante o êxodo rural, aumento dos índices inflacionários, as greves e a desordem geral, eventos que marcaram a saída dos militares após 21 anos de poderio e o retorno dos governos civis ao poder, momento em que o foi eleito o primeiro presidente civil do Brasil.

Apesar dos fatos precedentes, as eleições ocorridas em 1984 foram indiretas, mas levaram à Presidência da República um civil, o então governador de Minas Gerais, pelo PMDB, Tancredo Neves, que adoeceu antes de tomar posse e faleceu em 21 de abril de 1984, causando grande estranhamento e certa comoção popular.

Após fervorosa discussão nacional acerca da necessidade ou não de serem convocadas novas eleições presidenciais, assumiu a presidência do Brasil o vice de Tancredo Neves, José Sarney, membro da aristocracia maranhense, sendo que, sob seu governo, foi elaborado o texto de uma nova Carta constitucional que refletisse os novos rumos da democracia e da liberdade, promulgada em 05 de outubro de 1988, sobre a qual comenta Bonavides:

A Constituição de 1988 é, basicamente, em muitas de suas dimensões essenciais, uma Constituição do Estado social. Portanto, os problemas constitucionais referentes a relação de poderes e exercício de direitos subjetivos têm que ser examinados e resolvidos à luz dos conceitos derivados daquela modalidade de ordenamento (BONAVIDES, 2010, p. 371).

A Constituição de 1988 foi o resultado de uma Assembleia Nacional Constituinte, confirmada por voto popular após o fim do regime ditatorial. Ainda nesta direção, assumiu uma caracterização de conformação de um Estado de bemestar social.

Considerada um marco para o Direito Ambiental brasileiro, a Constituição de 1988 traz o Artigo 225, exclusivamente reservado ao meio ambiente ${ }^{22}$. Na referida Carta Magna, as questões ambientais e o direito ao meio ambiente são implementados constitucionalmente, juridicamente e explicitamente pela primeira vez na história política e jurídica do Brasil.

Em que pese o fato do Artigo 225 ser um único artigo, o mesmo tem uma gama de disposições importantes, cuja proteção explicitada é intergeracional. Ou

\footnotetext{
22 Art. 225. Todos têm direito ao meio ambiente ecologicamente equilibrado, bem de uso comum do povo e essencial à sadia qualidade de vida, impondo-se ao poder público e à coletividade o dever de defendê-lo e preservá-lo para as presentes e futuras gerações.
} 
seja, "destina-se não somente aos seres humanos que hoje habitam o planeta, mas também àqueles que ainda estão por nascer" (DANTAS, 2012, p. 38).

O referido dispositivo constitucional afirma que o meio ambiente é "bem de uso comum do povo". Significa que não pertencem ao poder público ou ao particular, mas integra categoria diversa de bens metaindividuais ou transindividuais. Ou seja, são bens coletivos de terceira geração (DANTAS, 2012).

Nesta breve trajetória político-jurídica ambiental apresentada, o art. 225 da $\mathrm{CF} / 88$ e a PNMA, podem ser considerados os principais instrumentos legais de proteção ao meio ambiente na atualidade.

Considerando que as políticas ambientais se referem a movimentos articulados com vistas a estabelecer mecanismos capazes de promover a utilização dos recursos de forma que proporcionem o desenvolvimento sustentável, a PNMA pode ser considerada um dos pilares desse sistema, ou seja, uma das parcelas mais importantes para a legislação ambiental nacional, na medida em que "os princípios constantes nela representam uma orientação prática à ação governamental" (ANTUNES, 2017, p.106).

As principais atribuições da PNMA caracterizam-se por fixar princípios, diretrizes e parâmetros normativos capazes de assegurar a sustentável utilização dos recursos naturais. Para tal finalidade, a PNMA conta com instrumentos que possibilitam a consecução de suas atividades, bem como com o apoio do SISNAMA ${ }^{23}$ e do CONAMA24, órgãos auxiliares deste sistema.

Com base em tais perspectivas, bem como no avanço técnico dos conceitos inerentes ao ecossistema, alcança-se uma visão mais ampla, tanto pela doutrina jurídica, como pela sociedade acerca das demais categorias vinculadas. Pacificou-se que o meio ambiente se caracteriza não só pela natureza, mas adicional e complementarmente pela atividade antrópica e demais condições implementadas pelo ser-humano, razão pela qual se desenvolveu o Direito Ambiental. Sob tais pressupostos, Antunes esclarece: "É claro que, ao tratarmos de Direito Ambiental,

23 SISNAMA é o Sistema Nacional do Meio Ambiente: criado com o art. $6^{0}$ da Lei 6938/81, caracteriza-se por um conjunto de órgãos com atribuições próprias. É um órgão superior que tem por função primordial exercer o poder de polícia em matéria ambiental. Ex.: fiscalização das atividades degradadoras do meio ambiente, com o objetivo de executar, em âmbito nacional, a Política Nacional do Meio Ambiente;

${ }^{24}$ CONAMA é o Conselho Nacional do Meio Ambiente: criado pelo art. $6^{\circ}$ da Lei 6938/81, com a finalidade de assessorar, estudar, propor ao conselho de governo diretrizes e políticas governamentais e deliberar sobre normas e padrões compatíveis com o meio ambiente ecologicamente equilibrado. É um órgão atuante que possui duas obrigações: consultivo e deliberativo. Ex.: controle da qualidade do ar-CONAR; 
não estamos falando de toda e qualquer atividade humana. Estamos fazendo referência especialmente às atividades que afetam direta ou indiretamente as águas, a fauna, as florestas, o solo e o ar" (ANTUNES, 2017, p. 02). Ainda nesta direção, e vinculado ao debate ambiental, conclui Antunes:

Entendo que o Direito Ambiental pode ser compreendido por um direito que tem por finalidade regular a apropriação econômica dos bens ambientais, de forma que ela se faça levando em consideração a sustentabilidade dos recursos, o desenvolvimento econômico e social, assegurando aos interessados a participação nas diretrizes a serem adotadas, bem como padrões adequados de saúde e renda (ANTUNES, 2017, p. 09).

Assim, verifica-se que, normativamente, o conjunto da legislação ambiental brasileira é consequência da busca da harmonia entre diversos dispositivos que objetivam a defesa do meio ambiente e dos bens naturais, razão pela qual faz uma interseção entre as normas de natureza ambiental e àquelas que se referem aos direitos individuais do cidadão. Contudo, no momento da aplicabilidade de tais preceitos pelo Estado, ou seja, no instante em que se faz necessário efetivar e executar as normas ambientais já publicadas, no âmbito do território nacional, verifica-se uma intensa e contínua influência do setor econômico neste processo.

Sob tais premissas, é possível considerar que, desde os períodos colonial, imperial e republicano, as questões ambientais foram ao longo do percurso político, econômico e social brasileiro, objeto de interesse de grupos econômicos específicos.

Por tais razões, faz-se imperioso constatar que as reflexões ambientais e a própria lei estão diretamente relacionadas às vicissitudes inerentes aos discursos políticos e econômicos, como identifica Wainer:

Verificou-se que em determinadas épocas existiam dispositivos muito avançados. Contudo, esses Ordenamentos eram ineficazes, pois a população não tinha um sentimento de amor e valorização da coisa pública nacional. A História nos mostra que há vários séculos já havia a noção do bem público de uso comum do povo. No entanto, o individualismo e a ganância de certos segmentos da sociedade se sobrepuseram ao interesse coletivo (WAINER, 1993, p. 206).

A partir da perspectiva até aqui apresentada é possível considerar que, apesar do contexto histórico comprovar que há muitos séculos já existia o conceito de bens necessários e indispensáveis à coletividade, pouca legislação vigorava com o intuito de manter, equalizar e preservar estes bens. 
Como consequência, a sociedade brasileira e mundial contemporânea se encontra diante da necessidade de gerir os bens naturais em constante movimento periódico de superação - ponderando-se as peculiaridades, as limitações e as condições de cada região - para afirmar estratégias de desenvolvimento integralizado. Isto porque não há relação harmônica, seja nacional ou internacional, entre produção, meio ambiente e desenvolvimento econômico que mantenha um equilíbrio entre a sociedade e a natureza, proporcionando a possibilidade da manutenção da vida com qualidade. Nesta direção, prossegue Antunes:

O grau maior de proteção ambiental é uma razão direta do maior nível de bem-estar social e renda da população. Por isso, as principais declarações internacionais sempre enfatizam a necessidade de desenvolvimento econômico, o qual deverá ser sustentável (ANTUNES, 2017, p. 19).

A partir de tais pressupostos, é permissível constatar que a racionalidade jurídica apresentada, seja no âmbito legislativo ou no que tange à efetivação e aplicabilidade das normas ambientais, está direta e absolutamente vinculada aos discursos sociais, políticos e econômicos do período, legitimando, ou mesmo deslegitimando ações e práticas em relação ao meio ambiente e à vida humana.

As consequências oriundas da trajetória jurídica, política e econômica são enfrentadas pela população brasileira, mesmo depois de decorridos mais de 500 (quinhentos) anos após a colonização do país. Tais impactos se apresentam na intensa extração e exploração dos bens naturais e a consequente transformação dos bens em recursos, mediante a intensa utilização do trabalho humano, para o controle, produção, circulação e consumo dos produtos.

\section{Considerações Finais}

Sob os preceitos legais históricos apresentados neste artigo, é possível identificar que o legado herdado do Brasil colonial e que se perpetua até os dias atuais traduz-se nas práticas inerentes à significativa concentração de terras produtivas sob o domínio de grandes potências mundiais, causando o intenso e contínuo desaparecimento de pequenos produtores e dos agricultores de subsistência que, em razão da perda, venda ou desapropriação das terras cultivadas, se veem forçados a abandonar a produção agrícola e muitas vezes migrarem para 
trabalhar como operários assalariados em centros urbanos.

Sob tais perspectivas, verifica-se que esta condição exploratória é fato continuado e reincidente no Brasil e nos demais países marginalizados, desde os primórdios coloniais. Um exemplo desta interferência extrativista exercida pelos oligopólios nos países colonizados é a implementação de monoculturas, extração mineral, dentre outras iniciativas devido às condições naturais e favoráveis. Ou seja, países que dispõem principalmente de muito sol, solo, água e biodiversidade.

Neste contexto de concentração de rendas, bens e recursos sob a administração de uma pequena parcela de pessoas e empresas mundiais, é permissível a constatação de severas concorrências, como as disputas desleais, guerras entre países pelas conquistas de mercado e obtenção de matéria-prima, bem como a instituição e manutenção da dívida externa, submetendo os países periféricos ou colonizados à condição de reféns dos países colonizadores ou desenvolvidos.

Diante desta racionalidade econômico-jurídica, seja no âmbito legislativo ou no que tange à efetivação e aplicabilidade das normas ambientais, os atos estão direta e absolutamente vinculados aos discursos sociais, políticos e econômicos do período, legitimando, ou mesmo deslegitimando ações e práticas em relação ao meio ambiente e à vida humana.

Afinal, tais perspectivas argumentativas podem ser evidenciadas não somente no cenário nacional, mas, inclusive, regionalmente, especialmente no território do Planalto Norte Catarinense, o qual foi submetido historicamente a intenso processo de exploração dos bens naturais, sob o pretexto do fomento econômico, especialmente pelas grandes corporações que exploram e desenvolvem monoculturas.

Assim, o extrativismo se caracteriza, majoritariamente, por atividades de alto impacto ambiental e de baixa intensidade tecnológica, social e humana, razão pela qual é permissível constatar que referido manejo produz significativos impactos ambientais regionais. Isto porque as monoculturas impedem a diversificação produtiva que poderia ser desenvolvida na área, bem como geram poucos empregos e a significativa maioria deles de baixa renda. Ademais, a silvicultura, por exemplo - atividade predominante na região Norte do Estado de Santa Catarina - tem amplo e extenso ciclo de produção, razão pela qual impossibilita ou não propicia melhoras ao ecossistema ou à qualidade de vida da população. 
Assim, desde o período colonial até a atualidade, os bens naturais do território brasileiro foram e estão sendo saqueados e depredados em nome de um suposto desenvolvimento econômico que apenas contabiliza o fluxo de produtos, mercadorias em prol de algumas pessoas ou empresas, sejam nacionais ou transnacionais. Neste contexto, não são respeitados os povos nativos, suas vidas, culturas, costumes e outros. De igual modo, não se considera o tempo geológico da terra ou o tempo da natureza e os elementos naturais que dela fazem parte. Diante disso, urge a necessidade premente e urgente de pensar e agir em prol do respeito aos povos nativos e seus descentes, bem como, de uso parcimonioso e de cuidado com os bens naturais na perspectiva de legar para as gerações futuras.

\section{Referências}

ANTUNES, Paulo de Bessa. Direito Ambiental. 19a edição. São Paulo: Atlas, 2017.

BACON, Francis. Novum Organum. Tradução e notas de José Aluysio Reis de Andrade. 2002. E-book disponível em http://odialético.hpg.com.br; Acesso em 10 de junho de 2019.

BONAVIDES, Paulo. Curso de Direito Constitucional. $25^{\mathrm{a}}$ ed. atualizada. Ed. Malheiros, 2010.

BRASIL. Constituição (1988). Constituição da República Federativa do Brasil. Brasília, DF: Senado Federal: Centro Gráfico, 1988.

BRASIL. Lei 6938/1981. Política Nacional do Meio Ambiente. Brasília, DF: Senado Federal: Centro Gráfico, 1981.

BRASIL. Decreto Federal n. 9.810, de 30 de maio de 2019. Institui a Política Nacional de Desenvolvimento Regional. Brasília, DF: Presidência da República. Disponível em www.planalto.gov.br. Capturada em o6 ago. 2019.

CASTRO, José Duarte de. Carta de Pero Vaz de Caminha a El Rei D. Manuel sobre o achamento do Brasil. Editora Marim Claret. Coleção a Obra Prima de cada Autor. São Paulo, 2002.

CUNHA, Luiz Fernando Whitaker da. Direito Constitucional do Brasil. Rio de Janeiro. Ed. Renovar, 1990.

FAORO, Raimundo. Os Donos do Poder: formação do patronato político brasileiro. $3^{\text {a }}$ edição revisada. São Paulo: Globo, 2001.

LEI FEDERAL No. 9.975 de 27 de abril de 1999. 
MARCHESAN, Jairo. Planalto Norte Catarinense: algumas considerações sobre os aspectos históricos, característica físico-naturais e extrativismo/Alexandre Tomporoski. Revista de Desenvolvimento Regional em Debate (ISSNe 2237-9029) v.6, n. 2, ed. esp., p.51-63, jul 2016. Acesso em 18-122019 http://www.periodicos.unc.br/index.php/drd/article/view/1206;

PORTO-GONÇALVES, Carlos Walter. A globalização da natureza e a natureza da globalização. Rio de Janeiro: Civilização Brasileira, 2006.

VAINER, Bruno Zilberman. Breve histórico das constituições do Brasil e o controle de constitucionalidade brasileiro. Revista Brasileira de Direito Constitucional - RBDC n. 16 - jul./dez. 2010. Pp 161 a 191.

VIPIEVSKi JÚNIOR, José Mário e MARCHESAN, Jairo. Don Pedro II - o Imperador ambientalista. Jornal virtual JMais Notícias. Canoinhas, 21.03.2021.

Recebido em: 16/07/2021. Aprovado em: 28/12/2021. Publicado em: 28/12/2021. 